\title{
Juridical Analysis of the Legal Results of the Binding Agreement of Sale and Purchase with a Deed under the Hand Endorsed by a Notary after the Judge's Decision Number 54 /PDT.G/2014/PN.PDG
}

\author{
Monicadia; Azmi Fendri; Khairani \\ Notary Masters Program, Faculty Of Law, Andalas University, Indonesia
}

http://dx.doi.org/10.18415/ijmmu.v6i5.1091

\begin{abstract}
Notary is authorized to authorize the letter under hand (legalization). The legalization process is a letter made under the hand signed by the parties before the Notary and the notary register the deed into a special book, for example a binding sale and purchase agreement. The author is interested in discuss1) What is behind the occurrence of the case Decision Number 54 /Pdt.G/2014/PN.Pdg? 2)How the judge's consideration of the sale and purchase agreement binding made and approved by the notary in the case Decision Number 54 /Pdt.G/2014 /PN.Pdg? The research method used is the method of juridical normative empirical approach. The result of the research 1) The background of the occurrence of the Decision Number 54 /Pdt.G/2014/PN.Pdg is that Defendant I did not carry out the payment of the Plaintiff's land sale and purchase of the above land, both the second term and the third termin payment, causing such a large loss Plaintiffs, such losses include the Plaintiff can not utilize the land sale money optimally, the Plaintiff has sought constantly to pursue the path of peace to find a way of settlement but Defendant I always tried to dodge so as not to meet common ground, 2) Judge's consideration of the binding agreement Sale and purchase made and approved by a notary in the case of Decision Number 54 /Pdt.G/2014/PN.Pdg is the object of PPJB is a plot of land that has been certified shall be held a local examination by the Assembly, the TRTB Service does not issue permits for the location of housing on land SHM .No.4065 / Balai Gadang with the reason that evidently the land is located just above the ground which is the plan of the road or in the area of the eastern ring road of the city of Padang. This is contrary to the IPPT issued by the Land Office of Padang City and the Sale and Purchase of Land of SHM.No.4065 / Balai Gadang has been declared void in accordance with the provisions of Article 5 of the Agreement dated September 13, 2013, that both parties agree to the costs incurred in The process of reversing the name of the land certificate either on a Notary which makes the deed or administrative process in the Land Affairs office of Padang city. Therefore, please punish the plaintiff for reconstruction and defendant to pay as much $(50 \%$ each) the costs incurred in the process behind the name SHM.No.4065 / Balai Gadang.
\end{abstract}

Keywords: Binding Agreement of Sale Purchase; Deed Under the Hand; Notary Public 


\section{Background}

The notary public is authorized to make an authentic deed and other authority regulated in Act Number 2 of 2014 concerning Amendment of Law Number 30 of 2004 concerning Notary Position (hereinafter referred to as Notary Position Law). Pursuant to Article 1 paragraph (1) of the Notary Position Law, namely: "a notary public official authorized to make an authentic deed and other authorities regulated in Act Number 2 of 2014 concerning Amendment to Law Number 30 of 2004 concerning Notary Position ( hereinafter referred to as the Law of Notary Position)". A notary as an official is a place for someone to obtain reliable advice. Everything written and determined (Constantine) is true, he is a strong document maker in a legal process ${ }^{1}$.

In arranging the interpersonal life of individuals who need a proof of legal relations between their fellow individuals, R. Soegondo Notodisoerjo said "a notary who in his profession is actually an institution whose deeds give rise to written and authentic evidences, which later as proving tools. The position of the Notary Public as a functionary in the community, is still considered still respected. A notary as an official is a place for someone to obtain reliable advice. Everything that was written and determined (Constantine) is true, he is a strong document maker in a legal event ".

The notary is made a public official, so that the deed made by the notary in his position obtains the nature of an authentic deed, the deed made by a notary has an outward nature not because the law stipulates so, but because the deed was made by or in front of the public official. referred to in Article 1868 of the Civil Code (Civil Code) which states: "an authentic deed is a deed in the form determined by the law, made by or in front of public officials in power for that at the place where the deed was made. .

The public officials in power referred to here are notaries. So the deed made by a notary is an authentic deed, while that not made by a notary becomes a deed under the hand. This is regulated in Article 1874 of the Civil Code, which states:

As underhanded writings are considered underhand deeds, letters, registers, household matters and other writings made without the mediation of a general official.With the signing of a writing under the hand, it is likened to affixing a thumbprint with a statement dated from a notary or other official appointed by the law which states that the affixer of the thumbprint is known by him or has been introduced to him, that the deed has been explained to the person that, and that after that the thumbprint is affixed to the text in front of the official concerned. This employee must prove the writing. By law further regulations can be made regarding the statement and bookkeeping.

Based on Article 1868 of the Civil Code above, it can be seen that there are two forms of deed, namely the deed made by a notary (relaas deed) and the deed made before a notary (partij deed). A voluntary deed is a form of deed made for evidence by the registrant, wherein the deed is outlined in an action taken or a situation seen or witnessed by the notary in carrying out his position as a notary public ${ }^{2}$. Deed that is made on the basis of what is seen and witnessed by a notary is known as a deed drawn up by a Notary. Deed made before a notary (party deed) is a deed made before a notary at the request of the parties, the notary is obliged to listen to the statements or statements of the parties stated or explained by the parties before the notary ${ }^{3}$.

\footnotetext{
${ }^{1}$ Tan Thong Kie, 2000, Buku I Studi Notariat Serba-Serbi Praktek Notaris, cet. 2, Jakarta, PT. Ichtiar Baru Van Hoeve, p 157.

${ }^{2}$ Herlin Budiono, 2013, Dasar Teknik Pembuatan Akta Notaris,PT.Citra Aditya Bakti, Bandunng, p. 8.

${ }^{3}$ Habib Adjie, 2011, Aspek Pertanggung Jawaban Notaris Dalam Pembuatan Akta, CV Mandar Maju, Bandung, p. 45.
} 
The position of the notary is held or his presence is desired by a rule of law with a view to assisting and serving the public who need written evidence that is authentic about the circumstances, events or legal actions. Thus the Notary is a position (public), has the following characteristics ${ }^{4}$ :

1. As a position.

The Notary Position Act is a unification in the field of notary position management, meaning that the only legal rule in the form of a law governing the position of Notary in Indonesia must refer to the Notary Position Act. The position of notary is an institution created by the state. Placing a notary public as a position is a field of work or assignment that is deliberately made by the rule of law for certain needs and functions (certain authorities) and is continuous as a permanent work environment.

2. The notary has certain authority.

Every authority given to a position must have a rule of law. As a limitation so that the position can run well, and not collide with the authority of other positions. Thus if an official (notary) performs an action outside the specified authority, it can be categorized as an act that violates the authority. The authority of a Notary Public is stated in Article 15 of the Law of Notary Position, namely:

1) Notary is authorized to make authentic deeds regarding all deeds, agreements, and provisions required by legislation and / or desired by the parties concerned to be stated in authentic deeds, guaranteeing the certainty of the date of making the deed, keeping the deed, giving the gross, copy and quotation of deeds, all of them as long as the making of the deeds are also assigned or excluded to other officials stipulated by the Act.

2) In addition to the authority referred to in paragraph (1), the Notary also has the authority:

a. To approve the signature and determine the certainty of the date by registering in a special book;

b. Book the letters under the hand by registering in a special book;

c. Make copies of original letters under the form of a copy containing the description as written and described in the relevant letter;

d. To validate the compatibility of the photocopy with the original letter;

e. Provide legal counseling in connection with the making of the deed;

f. Make a deed relating to land; or

g. Make an auction treatise deed.

3) In addition to the authorities as referred to in paragraph (1), and (2) the Notary Public shall have other authorities as stipulated in the legislation.

3. Appointed and dismissed by the Government.

Article 2 The Notary Position Law stipulates that the notary is appointed and dismissed by the Government, in this case the Minister in charge of notary publicity (Article 1 number 14 of the Notary Position Law), even though administratively appointed and dismissed by the Government, does not mean that the notary becomes subordinated (subordinate) who appointed him the Government. Thus the notary in carrying out the duties of his position:

\footnotetext{
${ }^{4}$ Habib Adjie, 2007, Hukum Notaris Indonesia Tafsir Tematik Terhadap UU Nomor 30 Tahun 2004 tentang Jabatan Notaris, Refika aditama, Surabaya, p. 14-16
} 
a. Be independent.

b. Do not side with anyone

c. It does not depend on anyone, which means that in carrying out its duties it cannot be interfered with by the party that appointed it or by other parties.

4. Do not receive a salary or pension from the person who raised it.

Notary, although appointed and dismissed by the Government but does not receive a salary, retired from the Government. Notaries only receive honoraria from the communities they have served or can provide free services to those who cannot afford it.

5. Accountability for work to the community.

The presence of a notary to serve the public who need an authentic legal document (deed) in the field of civil law, so the notary has the responsibility to serve the community, the community can sue a civil suit to the notary public, claim fees, compensation and interest if it turns out that the deed can be proved to be made incompatible premises applicable law, this is a form of accountability to the public notary.

Duties and authority of the Notary are closely related to the agreements, acts and also the provisions that give rise to the rights and obligations between the parties, namely to provide guarantees or evidence of the actions, agreements, and also the provisions so that the parties involved in it have legal certainty $^{5}$. In addition to making words in the form of a voluntary and partij deed, the notary is also authorized to ratify the letter under his hand and determine the certainty of the date by registering it in a special book (legalization) as stipulated in the Law of Notary Position. The notary authority to make this legalization is regulated in Article 15 Paragraph (2) letter a of the Law of Notary Position, states "ratifying the signature and determining the certainty of the date by registering in a special book".

The legalization process is carried out, where the parties whose names are mentioned in the underhanded hand come to the notary and notary to read the deed which has been drafted beforehand by the parties, if the deed is deemed to have fulfilled the legal requirements of the agreement as stated in Article 1320 of the Civil Code then the notary will read the deed to the parties, then the parties sign the deed witnessed by the Notary and the notary registers the deed into a special book (legalization).

In this case the notary is only responsible for the validity of the signature listed in the undersigned letter authorized by the notary public. The notary public as the official who has the authority to authorize a letter under the hand must be able to take responsibility for the letter under the hand that is endorsed by a notary (legalization) if it turns out in the future the problem of legalization arises. In addition, problems arising from the deed made by the notary need to be questioned, whether due to the mistake of the Notary or the mistakes of the parties who did not provide information, documents needed honestly and completely to the notary.

The notary liability for undersigned documents notarized also occurs between the seller's and the buyer's agreement to make an agreement made with a letter of agreement under the hand (legalization) with Number: Leg.1853 / IX / 2013 made on September 13 2013, where the settlement reached the Padang District Court Decision Number 54 / Pdt.G/2014/PN Pdg, with a description of the case:

\footnotetext{
${ }^{5}$ Habib Adjie, 2008, Sanksi Perdata dan Administritif Terhadap Notaris Sebagai Pejabat Publik, PT. Refika Aditama, Bandung, p. 32 .
} 
1. The parties

a. Plaintiff: Marhamis (Seller)

b. Interrupted:

1) Zarmias Amin: (Buyer) / Defendant I

2) Notary / PPAT: Defendant II

3) BPN Padang City: Defendant

2. The object of the agreement

a plot of land covering an area of 9,077 M2 (nine thousand seventy-seven square meters) located in Balai Gadang Village, Koto Tangah Sub-District, Padang City, known as Ownership Certificate Number: 4065 / Balai Kelurahan, Gadang Measurement Letter on June 16, 2011, Number 2433/2011, recorded in the name of MARHAMIS

3. Land prices

The land price is Rp.105,000 (one hundred and five thousand rupiahs per square meter), so the Plaintiff's selling price is Rp.105,000 X 9,077 M2 = Rp.953. 085,000 (nine hundred fifty three million eighty five thousand rupiah).

4. The payment phase is carried out in stages, namely:

a. On September 12, 2013 a down payment of Rp.400,000,000 was paid to the seller (four hundred million rupiah).

b. On October 25, 2013 a total of Rp.200,000,000 (two hundred million rupiah) was paid and the remaining Rp.353,085,000 (three hundred fifty-three million eighty-five thousand rupiah).

c. On December 25, 2013 amounting to Rp.353. 085,000 (three hundred fifty three million eighty five thousand rupiah) will be paid to the seller.

5. The seller submits a lawsuit to the Padang State Court because:

a. Buyer / defendant I has not paid the second Term of Rp.200,000,000 (two hundred million rupiahs) and the obligation to pay the third termin (settlement) of Rp.353,085,000 (three hundred fifty three million eighty-five thousand rupiah) until now Buyer / Defendant.

b. The certificate has been renamed on behalf of the Buyer / Defendant I and has been controlled by the seller so that the buyer defaults.

The notary liability for a binding purchase agreement made under the hand with Number: Leg.1853 / IX / 2013 dated September 13, 2013, in the Agreement under the hand (legalization) made under the notary as a defendant to explain the problems that occur between the seller and buyers. The binding purchase agreement is made because the payment is made in stages by the buyer. The seller filed a lawsuit with the Padang District Court because:

a. The buyer / defendant I has not yet paid the second Term of Rp.200,000,000 (two hundred million rupiah) and the obligation to pay the third Term (settlement) of Rp.353,085,000.- (three hundred fifty-three million eighty-five thousand rupiah) until now Buyer / Defendant.

b. The certificate has been renamed on behalf of the Buyer / Defendant I and has been controlled by the seller so that the buyer defaults. 
In the case of Decision Number 54 / Pdt.G/2014/PN Pdg, notary involvement is described as follows:

a. Notary who has made a legalized agreement and

b. Carrying out the process behind the name of the seller's name while the sale price has not been paid by the buyer.

In the trial process of Decision Number 54 /Pdt.G/2014/PN Pdg, responsibility is requested to provide information about the problem and be used as Defendant II in Case Number 54 /Pdt.G/2014/PN Pdg. The involvement of the notary must share responsibility for what he has done.

Based on the description above, the writer is interested in writing an article entitled Jurisdict Analysis of Legal Results of the Binding Agreement of Purchase With Under-Hand Deed which was notarized after the Judge's Decree Number 54 /Pdt.G/2014/Pn.Pdg?

\section{Problem Formulation}

Based on the description in the background above, the following problems can be formulated:

How is Juridical Analysis as a Result of the Legal Binding Agreement of Sale and Purchase With a Deed Under the Hand Endorsed by a Notary Public after the Judge's Decision Number 54 /Pdt.G/2014/Pn.Pdg?

\section{Discussion}

Juridical Analysis of Legal Results of the Binding Agreement of Sale and Purchase With a Deed Under the Hand Endorsed by a Notary Public after the Judge's Decision Number 54 /Pdt.G/2014/Pn.Pdg?

Legal consequences are the consequences caused by a legal relationship. The cause of the emergence of legal consequences is due to the law arises because of an act that does not meet the requirements both formal and material. For example in a legal agreement as regulated in Article 1320 of the Civil Code, if the subjective conditions are not fulfilled then the legal consequence is that the agreement can be canceled. If the objective conditions are not met then the legal consequence is a null and void agreement.

All consequences that occur from all legal actions carried out by legal subjects to the object of law or other consequences caused by certain events by the law in question have been determined or considered as legal consequences. Legal consequences are the source of birth of rights and obligations for the subjects of law concerned. For example, entering into a sale and purchase agreement, a legal consequence of the sale and purchase agreement is that there are legal subjects who have the right to obtain goods and have the obligation to pay for the goods. And vice versa other legal subjects have the right to get money but besides that he has the obligation to hand over goods, then the actions carried out by legal subjects against legal objects cause legal consequences. 
The types of legal consequences in the agreement can be divided into 4 (four), namely:

\section{Definition of Cancellation}

Any term used by the law all of which means null (netig). Cancellations can be divided in two, namely:

a. Violating the subjective conditions of the validity of the agreement (the conditions specified in Article 1320 paragraph 1 and 2 of the Civil Code), resulting in the agreement can be canceled (vernietigbaarheid).

b. Violating the objective conditions of the validity of the agreement (the conditions specified in Article 1320 of the Civil Code paragraphs 3 and 4 of the Civil Code), resulting in an agreement null and void (nietigbaarheid).

For agreements that can be canceled, the judge's ruling will read "canceling" constitutipal in nature (making the law). whereas for an agreement null and void, the judge's ruling will read "declare null" the declarative nature (referring to the law).

\section{Can be Canceled}

The agreement can be canceled if:

a. Violating the subjective conditions for the validity of the agreement, namely violating the provisions of Article 1320 paragraph 1 of the Civil Code (agreed those who bind themselves). Article 1320 paragraph 1 of the Civil Code states that the agreement is valid if between the parties agree to commit themselves. Legal disagreement (defect will / wilsgbrek) if given due to oversight, coercion and fraud (Article 1321 of the Civil Code). Agreements made with error, coercion and fraud issue a demand to cancel (Article 1449 of the Civil Code).

b. Violating the subjective conditions for the validity of the agreement, namely violating Article 1320 paragraph 2 of the Civil Code (the ability to make agreements). Article 1320 paragraph 2 of the Civil Code determines that an agreement is valid if the parties are competent in making an agreement. Minors and those under forgiveness are incompetent to act according to law.

c. Violating other provisions:

a. Abuse of the situation (undue influence). The definition of abuse of circumstances is a condition where in an agreement one of the parties takes an unnatural opportunity against a party whose position is weak. Or in an agreement, one party has a strong position, which position is abused by that party. Misuse of the situation relates to things which are casuistic in nature not related to those that are permanent as determined in Article 433 of the Civil Code namely: a fool, a person with a brain, a dark eye, a spender.

b. Mutual agreement

Article 1266 of the Civil Code determines that the conditions are canceled, are always considered to be included in the reciprocal agreement, and the cancellation must be requested from the judge, with the condition that the cancellation has fulfilled its obligations, while the other party does not. Requests for cancellation can be submitted based on an exception. The cancellation agreement to the court based on the provisions of Article 1266 of the Civil Code does not require the requirement "the debtor is declared negligent to fulfill the agreement in advance as regulated in Article 1243 of the Civil Code".

c. Actio Pauliana 
The statement of the debtor can request cancellation of the agreement made by the person who is in debt with another party, to the extent that the agreement is detrimental to him.

3. Cancel by law

An agreement is null and void if the agreement violates the objective conditions for an agreement, namely:

a. Violating the provisions of Article 1320 paragraph 3 of the Civil Code (A certain case).

A certain thing is meant that the agreement object must be certain, can be determined that is a commodity that can be traded, and the type can be determined, obviously, not blurred.

b. Violating Article 1320 paragraph 4 of the Civil Code (a lawful cause).

A lawful cause if the agreement is made based on a valid reason and justified by law. And do not violate the provisions regarding the contents of the agreement, for example:

1) It is prohibited to include in an agreement a condition that is not possible (Article 1254 Civil Code)

2) Prohibited from making agreements without a cause, a false cause, violating the law, contrary to decency, contrary to public order (Article 1335 in conjunction with Article 1337 of the Civil Code).

\section{Non Existent Agreement}

Covenants that do not fulfill the essential (absolute) element of an agreement. A nonexistent agreement is also called an agreement that has disappeared, for example:

a. Sale and purchase agreements, the essential elements are goods and prices, where in the agreement for example the essential element of price is not listed, so that the agreement becomes nonexistent, and therefore null and void.

b. A lease agreement, the essential element is the duration of the lease and the price of the lease, for example the duration of the lease is not included, so the agreement becomes nonexistent, therefore null and void 6 .

The legal consequences can also be seen in the binding sale agreement which is examined in this paper, in which there is one party that is in default or does not pay the land purchase payment while there has been a reverse name on behalf of the buyer. The seller submits a claim to the District Court, where the district court's decision does not accept the plaintiff's claim or escape. This is because :

1. The object in dispute must be subject to a local inspection and deposit the examination fee for inspection but the plaintiff does not deposit fees and is not prepared to carry out an inspection.

2. The TRTB Office does not issue permits for the location of housing on the land of SHM.No.4065 / Balai Gadang on the grounds that it turns out that the land is located directly above the land which is the road plan or within the area of the planned ring road east of the city of Padang. This is contrary to the IPPT issued by the Padang City Land Office.

By not conducting an examination which forms the basis for the panel of judges to decide on the case even though the sale price has not been paid in full and the certificate has been renamed on behalf of the buyer, the panel of judges still determines that the lawsuit cannot be accepted and punishes the

\footnotetext{
${ }^{6}$ I Ketut Artadi dan I Dewa Nyoman Rai Asmara Putra, 2010, Implementasi Ketentuan-Ketentuan Hukum Perjanjian kedalam Perancangan Kontrak, Udayana University Press, Denpasar, p. 71.
} 
plaintiff to pay the case fee. As a result, the legal consequences of the court's decision on the binding purchase agreement made by the parties are unclear because the plaintiff's claim stating the buyer defaulted was not accepted because the lawsuit was vague and there was no settlement.

In PPJB dated 13 (thirteen) December 2013 (two thousand and thirteen) it is clear the legal consequences arising if the buyer does not pay payment as stipulated in Article 5 PPJB dated 13 (thirteen) December 2013 (two thousand and thirteen), which reads:

If the second party cancels a sale and purchase transaction on the seller's land, the two parties agree that the sale and purchase is deemed canceled and the second party is obliged to sign the Deed of Sale and other necessary documents so that the certificate can be reversed in the name of the seller, a fee of each - each by $50 \%$ (fifty percent).

In cases involving a notary public as the author of an undisclosed letter in front of the notary public and carrying out the process of transferring the name to the name of the buyer, while the selling price agreed and regulated in the PPJB has not been paid by the buyer. The seller (the plaintiff) has reminded the seller to pay off the agreed sale and purchase price but the buyer (defendant I) has also not paid the sale price or broken the promise (default). The plaintiff filed a lawsuit with the Padang District Court and a mediation process had been carried out before the lawsuit was continued but no agreement had been reached. In this case the tribunal considers the subject matter of the dispute in this case, as follows:

1. The consideration regarding the PPJB object is that a piece of land that has been certified must be held locally by the Assembly, because the Assembly must first ascertain whether the object promised is there, and if there is any third party who controls this land but is not made a party in this case.

2. Ordered the Plaintiff through his attorney to hold a local inspection and also explained the importance of the local inspection, but until this case was decided by the Plaintiff, the attorney did not deposit the local inspection fee and was not prepared to carry out the local inspection;

3. Based on the aforementioned considerations with no local inspection being held on the object of the sale and purchase agreement of the land subject to dispute in this case, the Assembly is of the opinion that the Plaintiff's claim is obscured and therefore the Plaintiff's claim must be declared unacceptable.

4. The TRTB Service does not issue permits for the location of housing on the land of SHM.No.4065 / Balai Gadang on the grounds that it turns out that the land is located directly above the land which is the road plan or within the area of the planned ring road east of the city of Padang. This is contrary to the IPPT issued by the Padang City Land Office.

5. Sale and purchase of land SHM.No.4065 / Balai Gadang has been declared null and void so in accordance with the provisions in Article 5 of the Agreement dated September 13, 2013, that both parties agree on the costs incurred in the process of reversing the name of the land certificate, both to the Notary who made deed or administrative process at the Padang City Land office. Therefore, please punish the plaintiff's plaintiff and the plaintiff's plaintiff to pay as much $(50 \%$ each) costs incurred in the process behind the name of SHM.No.4065 / Balai Gadang. 
Based on the consideration of the panel of judges above Decision Number 54/Pdt.G/2014/PN.Pdg, the judge decides as follows:

1. The Plaintiff's claim cannot be accepted due to escape.

Plaintiff's claim is wrongly addressed (error in persona), because the plaintiff's claim regarding Default is the agreement made between Plaintiff and Defendant I as stated in the Agreement Letter dated September 13, 2013, No.Leg.1853 / IX / 2013 where Defendant III is not a party participated in the agreement so that the Plaintiff has no legal relationship with Defendant III.

2. Punish the plaintiff to pay the court fee which up to this day is set at Rp. 619,000 (six hundred and nineteen thousand rupiah).

Legal Consequences for the Binding Agreement of Purchase which was ratified by the Notary after the Decision of Judge Number 54 /Pdt.G/2014/PN.Pdg is unclear or there is no settlement because the lawsuit filed by the retraction is not accepted, but if it is reviewed legally the binding agreement sale and purchase is canceled and in accordance with Article 5 PPJB dated 13 (thirteen) December 2013 (two thousand and thirteen) where the certificate can be reversed on behalf of the seller, at a cost of 50\% (fifty percent) each because the TRTB Office does not issue permit for the location of housing on land SHM.No.4065 / Balai Gadang. Where during the buying and selling transaction the seller guarantees that the land purchased by the buyer can be built for housing.

\section{Conclusions}

Based on the description above, the following conclusions can be drawn:

Legal Consequences for the Binding Agreement of Purchase which was ratified by the Notary after the Decision of Judge Number 54 /Pdt.G/2014/PN.Pdg is unclear or there is no settlement because the lawsuit filed by the retraction is not accepted, but if it is reviewed legally the binding agreement sale and purchase is canceled and in accordance with Article 5 PPJB dated 13 (thirteen) December 2013 (two thousand and thirteen) where the certificate can be reversed on behalf of the seller and each fee is 50\% (fifty percent) because the TRTB Service does not issue permit for the location of housing on land SHM.No.4065 / Balai Gadang. Where during the buying and selling transaction the seller guarantees that the land purchased by the buyer can be built for housing. 


\section{References}

Books

Habib Adjie, 2007, Hukum Notaris Indonesia Tafsir Tematik Terhadap UU Nomor 30 Tahun 2004 tentang Jabatan Notaris, Refika aditama, Surabaya. , 2008, Sanksi Perdata dan Administritif Terhadap Notaris Sebagai Pejabat Publik, PT. Refika Aditama, Bandung

2007, Hukum Notaris Indonesia Tafsir Tematik Terhadap UU Nomor 30 Tahun 2004 tentang Jabatan Notaris, Refika aditama, Surabaya

Herlin Budiono, 2013, Dasar Teknik Pembuatan Akta Notaris,PT.Citra Aditya Bakti, Bandung.

I Ketut Artadi dan I Dewa Nyoman Rai Asmara Putra, 2010, Implementasi Ketentuan-Ketentuan Hukum Perjanjian kedalam Perancangan Kontrak, Udayana University Press, Denpasar

Tan Thong Kie, 2000, Buku I Studi Notariat Serba-Serbi Praktek Notaris, cet. 2, Jakarta, PT. Ichtiar Baru Van Hoeve

Legislations

Kitab Undang-Undang Hukum Perdata.

Undang-Undang Nomor 2 Tahun 2014 tentang Perubahan atas Undang-Undang Nomor 30 Tahun 2004 tentang Jabatan Notaris.

\section{Court Decision}

Putusan \{Pengadilan negeri padang Nomor: 54 /Pdt.G/2014/PN.Pdg

\section{Copyrights}

Copyright for this article is retained by the author(s), with first publication rights granted to the journal.

This is an open-access article distributed under the terms and conditions of the Creative Commons Attribution license (http://creativecommons.org/licenses/by/4.0/). 